\title{
Erratum to "Effect of rumen-protected choline on performance, blood metabolites, and hepatic triacylglycerols of periparturient dairy cattle" (J. Dairy Sci. 94:4016-4027)
}

\author{
R. L. G. Zom, J. van Baal, R. M. A. Goselink, J. A. Bakker, M. J. de Veth, and A. M. van Vuuren
}

The caption for Figure 3 (page 4025) contained several errors. The corrected caption should read as follows:

Figure 3. The modeled effect of choline supplementation on concentrations of triacylglycerols (TAG) in the liver of periparturient dairy cattle. Open bars = control treatment; solid bars $=$ choline treatment. Control: TAG $\log (\mathrm{g} / \mathrm{g}$ of wet tissue $)=4.24(\mathrm{SED}: 0.14)$ +0.0230 (SED: $0.0031 ; P<0.001) \times$ DIM -0.00114 $($ SED: $0.000124 ; P<0.001) \times \mathrm{DIM}^{2}$. Treatment effect:
-0.0330 (SED: $0.00969 ; P=0.001) \times \mathrm{TD}+0.000627$ $($ SED: $0.000175 ; P<0.001) \times \mathrm{TD}^{2} ; \mathrm{SED}=$ standard error of difference; $\mathrm{TD}=$ treatment day.

The authors regret the error.

\section{REFERENCES}

Zom, R. L. G., J. van Baal, R. M. A. Goselink, J. A. Bakker, M. J. de Veth, and A. M. van Vuuren. 2011. Effect of rumen-protected choline on performance, blood metabolites, and hepatic triacylglycerols of periparturient dairy cattle. J. Dairy Sci. 94(8):4016-4027. 